\title{
Evaluating adherence to long-term prophylaxis treatment with danazol in adult hereditary angioedema patients: A real life study
}

\author{
Erişkin herediter anjiödem hastalarında danazol ile yapılan uzun dönem profilaksi tedavisine \\ uyumun değerlendirilmesi: Gerçek bir yaşam çalışması
}

Semra DEMIR, Derya UNAL, Muge OLGAC, Asli GELINCIK, Raif COSKUN, Bahauddin COLAKOGLU, Suna BUYUKOZTURK

\begin{abstract}
Objective: To investigate the adherence to the prophylactic treatment in hereditary angioedema (HAE) patients as well as the potential factors which may affect this situation.

Patients and Methods: In addition to evaluation of their medical records, sixty HAE patients were asked to complete a questionnaire including inquiries about demographic and clinical features of their disease and medications used. Disease severity was determined depending on their age of onset of symptoms, clinical manifestations, and need of long-term prophylaxis.

Results: Sixty-five percent of the patients were female, the mean age was $38.07 \pm 12.38$ years, $93.3 \%$ were type $1 \mathrm{HAE}, 58.3 \%$ had a severe form of the disease, and $71.7 \%$ were under prophylaxis with danazol. Fourteen patients were not using danazol regularly due to the fear of side effects $(n=11)$ and forgetfulness to take the medication $(n=4)$. It was observed that the patients who were the only cases in their families, those having few relatives with HAE and having had no excitus due to HAE in their families, were more adherent to prophylactic treatment $(\mathrm{P}=0.008 ; \mathrm{P}=0.018 ; \mathrm{P}=0.028)$.

Conclusion: The majority of patients were effectively under long-term prophylaxis and the majority adhered to this treatment. The primary cause of non-adherence was fear of side effects.

Keywords: Adherence to treatment, Hereditary angioedema, Management, Long-term prophylaxis, Danazol, Side effects
\end{abstract}

Semra Demir ( $₫$ ), Asli Gelincik, Raif Coskun, Bahauddin Colakoglu, Suna Buyukozturk

Divison of Immunology and Allergic Diseases, Department of Internal Medicine, School of Medicine, Istanbul University, Fatih, Istanbul, Turkey e-mail: ertansemra@yahoo.com

Derya Unal

Adult Allergy and Immunology Clinic, Yedikule Chest Diseases and Thoracic Surgery Training and Research Hospital, Yedikule, Istanbul,Turkey Muge Olgac

Adult Allergy and Immunology Clinic, Sisli Hamidiye Etfal Training and Research Hospital, Sisli, Istanbul, Turkey

Submitted / Gönderilme: 28.08 .2018

Accepted/Kabul: 15.10.2018
ÖZ

Amaç: Herediter anjioödem (HAÖ) hastalarında profilaktik tedaviye uyumu ve bunları etkileyen olası faktörleri araştırmaktır.

Hastalar ve Yöntemler: Altmış HAÖ hastasının tıbbi kayıtları değerlendirildi ve demografik ve hastalıkları ile ilgili klinik özellikler ve kullandıkları ilaçlar ile ilgili soruları içeren anketi yanıtlamaları istendi. Hastalık ciddiyeti, semptomların başlangıç yaşı, klinik bulguları ve uzun dönem profilaksi ihtiyacına göre belirlendi.

Bulgular: Hastaların \%65'i kadın, yaş ortalaması $38,07 \pm 12,38$, \%93,3'ü tip 1 HAÖ, \%58,3'ünün hastalığ1 ciddi idi ve \%71,7'si danazol ile profilaktik tedavi görüyordu. Ondört hasta proflaktik tedavisini düzenli kullanmiyordu ve kullanmama nedenleri yan etki gelişmesinden korkmak $(n=11)$ ve ilacı almayı unutmak idi $(n=4)$. Ailede tek vaka olanların, HAÖ'li akrabası az olanların ve ailesinde bu nedenle hayatlarını kaybeden akrabası olmayanların profilaktik tedaviye daha uyumlu olduğu görüldü $(\mathrm{P}=0,008$; $\mathrm{P}=0,018 ; \mathrm{P}=0,028)$.

Sonuç: Hastalarımızın büyük çoğunluğu proflaktik tedaviyi düzenli kullanmakta ve bu tedaviden fayda görmektedir. Uyumsuzluğun primer nedeni yan etki gelişimi korkusudur.

Anahtar kelimeler: Tedaviye uyum, Herediter anjioödem, Tedavi, Uzun dönem profilaksi, Danazol, Yan etkiler

\section{Introduction}

Hereditary angioedema (HAE) is an orphan disease that develops due to the mutations in the SERPING1 gene. Mutations lead to deficiency (Type $1 \mathrm{HAE}$ ) or dysfunction (Type $2 \mathrm{HAE})$ in $\mathrm{C} 1$-esterase inhibitor $(\mathrm{C} 1-\mathrm{INH})$ protein [1]. The estimated prevalence of the disease ranges from $1 / 10.000$ to $1 / 100.000$ and is autosomal dominantly inherited $[1,2]$. The deficiency or dysfunction in $\mathrm{C} 1-\mathrm{INH}$ protein causes overproduction of bradykinin which in turn leads to increment of vascular permeability by affecting the bradykinin 2-receptors on endothelial cells [2,3]. This phenomenon clinically results in edema attacks in mucocutaneous tissues 
such as the face, the larynx, the gastrointestinal tractus, the genitalia, and the extremities [2]. The episodes in HAE are characterized by nonerythematous, nonpruritic and well-demarcated swellings without urticarial lesions and/ or abdominal pain [2]. The attacks can last 2-5 days and untreated larynx edema can result in death $[2,4]$. Accurate and early diagnosis is therefore very important in proper management of the diasease. Unfortunately, misdiagnosis is common, causing a delay in diagnosis and mistreatment, even unnecessary surgical interventions because of physician unawareness $[2,5,6]$.

The management of the disease includes avoidance of attacks with long or short term prophylaxis and treatment of acute attacks $[1,7]$. Plasma derived C1-inhibitor (pdC1INH) concentrates, the bradykinin-2 reseptor antagonist (icatibant) and kallikrein inhibitor (ecallantide) are used to treat acute attacks $[1,8]$ For patients who have frequent and severe attacks and those who do not have easy access to C1INH concentrates, long-term prophylaxis is recommended [1].By means of long-term prophylaxis using attenuated androgens, pdC1-INH and anti-fibrinolytics, frequency, duration and severity of episodes can decrease significantly $[1,9]$. Acute angioedema episodes lead to direct medical costs as well as reduced performance and/or absenteeism at work and school [10]. Moreover, since the attacks are imponderable, patients are negatively affected regarding quality of life issues and become depressive in the long term [11-13]. The prevention of acute attacks is therefore of outmost importance to improve patient quality of life. In chronic illnesses which need long-term drug usage, adherence to treatment can be a matter for both phsicians and patients.

Noncompliance with medication causes decreased efficacy and treatment failure as well as increased medical costs $[14,15]$. In our country, plasma derived C1-INH concentrates are not authorized for prophylaxis and the only available attenuated androgen used for the prophylactic treatment of adult HAE patients is danazol. However, insufficient data exists regarding the adherence rate of HAE patients to this prophylactic treatment.

We aimed to evalaute the adherence rate to the long-term prophylactic treatment with danazol in HAE patients and the potential factors which may affect this adherence.

\section{Patients and Methods}

We conducted an observational and retrospective study. The data were mainly collected from the medical records of the HAE patients followed in our adult Immunology and Allergy Clinic. Additionally, the patients were requested to complete a questionnaire, including various inquiries regarding demographic and clinical features, when they came for routine visits.

Patients were classified as adherent or nonadherent depending on the regularity of their adherence to prescribed prophylactic treatment. Nonadherence was defined as skipping at least twice the two or more consecutive recommended doses of the drug, depending on the half life of danazol, i.e, approximately 24 hours. Most of our patients use danazol once or rarely twice per day. Demographic and clinical features were compared between these two groups.

Disease severity was assessed with the general disease severity score developed by Bygum et al. This score ranges from 0 to 10 points (10 is the highest disease severity), does not consider any specific time and appraises the entire course of the disease from symptom onset to evaluated time (Table I) [16]. Score lower than 7 was accepted as mild to moderate disease; score of 7 or more was considered as severe disease [17].

To evaluate the efficacy of long-term prophylactic treatment, the frequency of attacks was compared before and after the initiation of treatment.

Ethical approval for this study was obtained from the Istanbul University, School of Medicine Ethical Committee (Number:753/ID:2016/735) and written informed consent was obtained from all patients.

Table I. Clinical severity score (cumulated 0-10 points) [16]

\begin{tabular}{|l|l|}
\hline Feature & Points \\
\hline Age at onset $0-5$ years & 3 \\
\hline Age at onset 6 -10 years & 2 \\
\hline Age at onset $11-20$ years & 1 \\
\hline Age at onset $>20$ years & 0 \\
\hline Skin edema ever & 1 \\
\hline Painful abdominal edema ever & 2 \\
\hline Laryngeal edema ever & 2 \\
\hline Other clinical manifestations & 1 \\
\hline Long term prophylaxis ever & 1 \\
\hline
\end{tabular}




\section{Statistical analysis}

The results were expressed as percentages and mean \pm standard deviation. The categorical and continuous variables were compared with chi square or Fisher's exact tests and independent Sample t Test or Mann-Whitney U test according to the distribution as normal or not. The frequency of attacks before and after long-term prophylaxis treatment was compared with Wilcoxon Signed Rank test. A 'P' value lower than 0.05 was accepted as significant.

\section{Results}

Sixty patients answered the questions. Sixty-five percent of the patients were female and the mean age was $38.07 \pm 12.38$ years. The mean general disease severity score was $6.7 \pm 1.63$ points and $58.3 \%$ of the patients $(\mathrm{n}=35)$ had severe disease. Most patients were type $1 \mathrm{HAE}(93.3 \%)$ and $4(6.7 \%)$ patients were type 2 and $71.7 \%(n=43)$ of the patients were under prophylaxis mostly with danazol. Only one patient used tranexamic acid. The mean duration of follow up under danazol was 63.51 \pm 35.1 months (min-max:6-140 months). In 12 patients danazol use was discontinued due to pregnancy $(\mathrm{n}=8)$, side effects involving secondary amenorrhea $(\mathrm{n}=2)$ and hypertension $(\mathrm{n}=1)$, and inefficacy $(\mathrm{n}=1)$. Fourteen patients were not using the prophylactic treatment regularly due to fear of development of side effects $(\mathrm{n}=11)$ and forgetfulness $(n=4)$. The mean age at development of first symptoms, age at diagnosis, and delay in diagnosis were $12.48 \pm 9.45$, $30.05 \pm 13.59$ and $17.02 \pm 12.95$ years, respectively. Nearly half $(56.7 \%)$ of the patients were misdiagnosed until the correct diagnosis was completed. In $13.3 \%$ of the patients, laparotomy surgeries (mainly appendectomy ) were performed during acute abdominal attacks. A quarter (23.3\%) of the patients were the sole cases in their families and $15 \%$ of the patients had lost their first degree relatives due to asphyxia. Detailed information about demographic and clinical features of the patients is shown in Table I. The frequency of the HAE attacks significantly decreased after treatment in patients who were under long-term prophylaxis as shown in Figure $1(\mathrm{P}<0.001)$.

Comparison of the demographic and clinical features of the adherent and nonadherent groups is given in Table II. It is observed that the patients who were the only cases in their families, those having less relatives with HAE, and ones with no excitus due to HAE in their families were more adherent to the prophylactic treatment $(\mathrm{P}=0.008 ; \mathrm{P}=0.018$; $\mathrm{P}=0.028$ ). The frequency of abdominal pain attacks were significantly lower in adherent group than nonadherent group and although, the frequencies of other types of attacks were less in adherant group there were no statistically significant differences between the groups. The mean dose of danazole was $100 \mathrm{mg} /$ day in both groups.

There were no correlation between disease severity and some factors such as age, gender, experiencing prodromal symptoms, having triggering factors in attacks, being a single patient and having excitus in their families. Also, disease severity did not affect the adherence to prophylaxis.

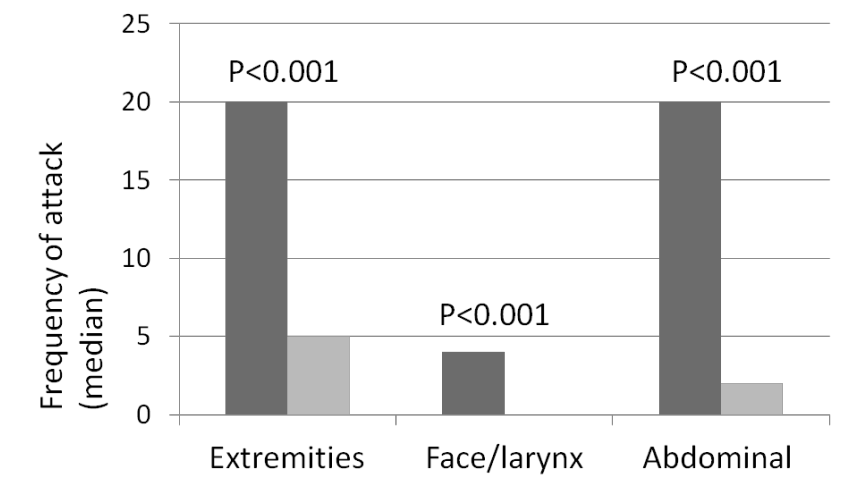

Figure 1. The frequencies of HAE attacks according to the site of attacks and before or during long-term prophylaxis treatment (LTP: Long-term prophylaxis) 
Table II. Demographic and clinical features of all patients and the comparison of these features with the adherent and nonadherent patients who are under long - term prophylaxis treatment

\begin{tabular}{|c|c|c|c|c|}
\hline & $\begin{array}{l}\text { All patients } \\
\mathrm{n}(\%)\end{array}$ & $\begin{array}{l}\text { Adherent to } \\
\text { prophylactic } \\
\text { treatment } \mathrm{n}(\%)\end{array}$ & $\begin{array}{l}\text { Not adherent } \\
\text { to prophylactic } \\
\text { treatment } \mathrm{n}(\%)\end{array}$ & $\mathrm{p}$ \\
\hline Female gender & $25(65)$ & $18(62.1)$ & $7(50.0)$ & NS \\
\hline \multicolumn{5}{|l|}{ Symptoms developed ever } \\
\hline Abdominal pain & $58(96.7)$ & $28(96.6)$ & $14(100)$ & NS \\
\hline Angioedema on face & $48(80)$ & $25(86.2)$ & $13(92.9)$ & NS \\
\hline Laryngeal angioedema & $41(68.3)$ & $21(72.4)$ & $11(78.6)$ & NS \\
\hline Angioedema on extremities & $57(95)$ & $27(93.1)$ & $14(100)$ & NS \\
\hline Misdiagnosis before diagnosis of HAE & $34(56.7)$ & $19(65.5)$ & $8(57.1)$ & NS \\
\hline Allergy & $12(20)$ & $7(24.1)$ & $3(21.4)$ & NS \\
\hline Familial Mediterranean Fever & $14(23.3)$ & $8(27.6)$ & $3(21.4)$ & NS \\
\hline Rheumatologic diseses & $3(5)$ & $2(6.9)$ & 0 & NS \\
\hline Colitis & $4(6.7)$ & $2(6.9)$ & $1(7.1)$ & NS \\
\hline Prodromal symptoms & $44(73.3)$ & $19(65.5)$ & $12(85.7)$ & NS \\
\hline Lassitude/Fatigue & $20(33.3)$ & $7(24.1)$ & $7(50.0)$ & NS \\
\hline Nausea & $14(23.3)$ & $4(13.8)$ & $4(28.6)$ & NS \\
\hline Tingling & $12(20)$ & $3(10.3)$ & $5(35.7)$ & NS \\
\hline Pain & $6(10)$ & $2(6.9)$ & $2(14.3)$ & NS \\
\hline Irritability & $3(5)$ & $1(3.4)$ & $2(14.3)$ & NS \\
\hline Other & $46(60)$ & $7(23.8)$ & $8(56.8)$ & NS \\
\hline Triggering factor & $56(93.3)$ & $26(89.7)$ & $14(100)$ & NS \\
\hline Stress & $49(81.7)$ & $22(75.9)$ & $14(100)$ & NS \\
\hline Fatigue & $23(38.3)$ & $7(24.1)$ & $7(50)$ & NS \\
\hline Trauma & $42(70)$ & $19(65.5)$ & $12(85.7)$ & NS \\
\hline Hormonal & $6(26.7)$ & $10(34.5)$ & $2(14.3)$ & NS \\
\hline Infections & $14(23.3)$ & $10(34.5)$ & $3(21.4)$ & NS \\
\hline Minor/major surgical interventions & $10(16.7)$ & $6(20.7)$ & $4(28.6)$ & NS \\
\hline Drug & $9(15)$ & $4(13.8)$ & $3(21.4)$ & NS \\
\hline Apandectomy & $8(13.3)$ & $5(17.2)$ & $1(7.1)$ & NS \\
\hline \multicolumn{5}{|l|}{ In family } \\
\hline Being single case & $14(23.3)$ & $11(37.9)$ & 0 & 0.008 \\
\hline Exitus due to this disease & $9(15)$ & $2(6.9)$ & $5(35.7)$ & 0.028 \\
\hline \multicolumn{5}{|l|}{ Attack treatment } \\
\hline To increase the dose of danazol & $7(11.7)$ & $4(13.8)$ & $3(21.4)$ & NS \\
\hline $\mathrm{C} 1$ inhibitor concentrate & $57(95)$ & $27(93.1)$ & $13(92.9)$ & NS \\
\hline Icatibant & $17(28.3)$ & $7(24.1)$ & $3(21.4)$ & NS \\
\hline \multirow[t]{2}{*}{ Fresh frozen plasma } & $2(3.3)$ & $1(3.4)$ & 0 & NS \\
\hline & Mean \pm SD/median & Mean \pm SD/median & Mean \pm SD/median & $\mathbf{P}$ \\
\hline Age (year) & $38,07 \pm 12,38$ & $38.3 \pm 12.2$ & $39.4 \pm 13.12$ & NS \\
\hline Age of onset of symptoms (year) & $12.48 \pm 9.45$ & 10 & 8.5 & NS \\
\hline Age of diagnosis (year) & $30.05 \pm 13.59$ & $29.2 \pm 14.5$ & $32.43 \pm 12.6$ & NS \\
\hline Time interval between onset of symptoms and diagnosis (year) & $17.02 \pm 12.95$ & $18.5 \pm 13.8$ & $19 \pm 14.79$ & NS \\
\hline Number of patients in the family & 2 & 2 & 4 & 0.018 \\
\hline Abdominal pain attacks in a year before diagnosis/treatment & $21.77 \pm 16.0$ & 20 & 22.5 & NS \\
\hline $\begin{array}{l}\text { Attacks of angioedema on face and/or larynx in a year before diagnosis/ } \\
\text { treatment }\end{array}$ & $8.98 \pm 11.72$ & 3 & 4.5 & NS \\
\hline Attacks of angioedema on extremities in a year before diagnosis/treatment & $26.22 \pm 21.48$ & 20 & 22.5 & NS \\
\hline Abdominal pain attacks in a year after diagnosis/treatment & $7.4 \pm 7.9$ & 2 & 5.5 & 0.031 \\
\hline $\begin{array}{l}\text { Attacks of angioedema on face and/or larynx in a year afterdiagnosis/ } \\
\text { treatment }\end{array}$ & $2.9 \pm 5.12$ & 0 & 0.5 & NS \\
\hline Attacks of angioedema on extremities in a year before diagnosis/treatment & $9.12 \pm 9.1$ & 5 & 7.5 & NS \\
\hline Dose of danazol (mg) & 100 & 100 & 100 & NS \\
\hline Number of $\mathrm{C} 1$ inh concentrates which were consumed in the last year & 3 & 2 & 3 & NS \\
\hline
\end{tabular}




\section{Discussion}

This study, to the best of our knowledge, is the first and sole study that evaluates the adherence to long-term danazol prophylaxis of HAE patients living in a developing country where the prophylactic treatment with plasma derived C1INH is not licensed.

One of the main findings of the study is that most patients were under long-term prophylaxis (71.7\%). The usage of longterm prophylaxis was higher in our study than the cohorts of the other countries in which it ranged from $23.2 \%$ to $56.3 \%$ $[5,11,17-21]$. As in our study, the most commonly used agent for long-term prophylaxis was attenuated androgen, namely danazol [11,18-20]. Attenuated androgens leading to an increase in plasma levels of C1-INH are useful agents in HAE patients to prevent acute attacks [22,23]. However, these androgens can cause adverse events involving liver toxicity and androgenic changes such as hirsutism and lipid profile disturbances; consequently careful follow-up is necessary in patients using these agents long-term [24,25]. Furthermore, their usage is contraindicated during pregnancy and breast feding and is problematic until puberty $[25,26]$. These problems could explain the propensity to avoidance of adherence to attenuated androgens in both patients and physicians. Currently, in most European countries, pdC1-INH concentrates are labeled as prophylatic agents and preferred as the first line prophylactic medications [27,28]. The opportunity of home treatment provides an important support for the preference of this medication. Whereas, in Turkey, pdC1-INH concentrates are not licensed for prophylaxis and used as off-label only in selected patients when needed. Furthermore, home treatment is also not authorized. For these reasons and the inclusion of only adult patients in the study, the frequency of long-term prophylaxis with danazol was higher in our cohort. Its lower cost and easy usage compared to C1-INH constitute its advantages [25]. The adverse events due to danazol are dose-dependent and the dosages below 200 $\mathrm{mg}$ /day are usually safe. In our patients, danazol was used effectively without any significant side effects. Therefore, in carefully selected patients, attenuated androgens could be used for long-term prophlaxis.

As another important finding of the study, most of the patients under long-term prophylaxis were adherent (67.5\%). The main reason for adherence was the efficiency of the drug in preventing serious attacks without causing an important side effect. The most common cause of nonadherence was fear of side effects ( $20.9 \%$ of nonadherers). Interestingly, patients with no family history, those having few relatives with HAE and those having had no excitus due to HAE in their families were more adherent to the prophylactic treatment.

In our series, the delay until HAE diagnosis was approximately 18 years, a finding from another major city in Turkey in accordance with those of Ucar et al. who reported a diagnostic delay of approximately 17 years [29]. However, the first hereditary angioedema study conducted in Turkey reported the mean delay time as approximately 26 years [30]. This change is a satisfactory one, suggesting that the awareness of the disease has increased over the years in our country, yet it is inadequate. The delay in diagnosis widely changes depending on the individual countries as well. Zanichelli et al., reported median delay of 8.5 years in Europe [31]. Sixteen years in China and an American study reported 21 years delay in diagnosis recently $[21,23]$. These results again underline the lack of awareness of HAE around the world. Therefore, more efforts and perhaps new ideas are needed to increase the knowledge of the disease among both physicians and the public.

The demographic features of our patients were in accordance with previous HAE cohorts from Turkey and other countries in most aspects. In the current study, the majority of the patients were female and the onset age of symptoms was approximately 12 years. These features were in line with previous studies $[8,19,30,33]$. The frequency of type II HAE in our study (6.7\%) was lower than some of the previous studies in which the frequencies were $15 \%$ and $20.3 \%[32,34]$ However, newer studies published similar prevalence of type II HAE ranging from $4.9 \%$ to $6.2 \%$ $[5,6,20,35]$.

In conclusion, most of the HAE patients in our group were effectively under long-term prophylaxis with danazol and the compliance with the long-term prophylaxis was high. The most common cause of not using danazol regularly was the fear of side effects. Furthermore, the patients who lost their relatives due to HAE attacks and had more ill relatives in the family were less adherent to the long term prophylactic treatment.

\section{References}

1. Cicardi M, Aberer W, Banerji A, et al. Classification, diagnosis and approach to treatment for angioedema: consesnsus report from the Hereditary Angioedema International Working Group. Allergy 2014;69:602-16. doi: 10.1111/all.12380

2. Zuraw BL. Hereditary angioedema. N Engl J Med 2008;359:1027-36. doi: 10.1056/NEJMcp0803977. 
3. Gompels MM, Lock RJ, Abinun $\mathrm{M}$, et al. $\mathrm{C} 1$ inhibitor deficiency: consensus document. Clin Exp Immunol 2005;139:379-94.

4. Zilberberg M, Jacobsen T, Tillotson G. The burden of hospitalizations and emergency department visits with hereditary angioedema and angioedema in the United States, 2007. Allergy Asthma Proc 2010;31:511-9. doi: 10.2500/ aap.2010.31.3403.

5. Roche O, Blanch A, Caballero T, Sastre N, Callejo D, LopezTrascasa M. Hereditary angioedema due to $\mathrm{C} 1$ inhibitor deficiency: patient registry and approach to the prevelance in Spain. Ann Allergy Asthma Immunol 2005;94:498-503.

6. Bygum A. Hereditary angioedema in Denmark: a nationwide survey. Br J Dermatol 2009;161:1153-8. doi: 10.1111/j.13652133.2009.09366.x.

7. Craig $\mathrm{T}$, Aygören-Pürsün $\mathrm{E}$, Bork $\mathrm{K}$, et al. WAO Guideline for the management of hereditary angioedema. World Allergy Organ J 2012;5:182-9. doi: 10.1097/ WOX.0b013e318279affa.

8. Caballero T, Baeza ML, Cabanas R, et al. Consensus statement on the diagnosis, management and the treatment of angioedema mediated by bradikynin. Part II. Treatment, follow up, and special situations. J Investig Allergol Clin Immunol 2011;21:422-41.

9. Costantino G, Casazza G, Bossi I, Duca P, Cicardi M. Longterm prophylaxis in hereditary angio-edema: a systematic review. BMJ Open 2012;2:e000524. doi: 10.1136/ bmjopen-2011-000524.

10. Wilson DA, Bork K, Shea EP, Rentz AM, Blaustein MB, Pullman WE. Economic costs associated with acute attacks and long term management of hereditary angioedema. Ann Allergy Asthma Immunol 2010;104:314-20. doi: 10.1016/j. anai.2010.01.024.

11. Lumry WR, Castaldo AJ, Vernon MK, Blaustein MB, Wilson DA, Horn PT. The humanistic burden of hereditary angioedem: Impact on health-related quality of life, productivity, and depression. Allergy Asthma Proc 2010;31:407-14. doi:10.2500/aap.2010.31.3394.

12. Nordenfelt P, Dawson S, Wahlgren CF, Lindfors A, Malbris L, Björkander J. Quantifying the burden of disease health state in patients with hereditary angiopedema in Sweeden. Allergy Asthma Proc 2014;35:185-90. doi: 10.2500/ aap.2014.35.3738.

13. Cabellero T, Aygören-Pürsün E, Bygum A, et al. The humanistic burden of hereditary angioedema: results from the Burden of Illness Study in Europe. Allergy Asthma Proc 2014;35:47-53. doi: 10.2500/aap.2013.34.3685.

14. Hughes DA, Bagust A, Haycox A, Walley T. Accounting for noncompliance in pharmacoeconomic evaluations. Pharmacoeconomics 2001;19:1185-97.

15. Hudhes DA. Economic impact of poor compliance with pharmaceuticals. Expert Rev Pharmacoecon Outcomes Res 2002;2:327-35. doi: 10.1586/14737167.2.4.327

16. Bygum A, Fagerberg CR, Ponard D, Monnier N, Lunardi J, Drouet C. Mutational spectrum and phenotypesin Danish families with hereditary angioedema because of $\mathrm{C} 1$ inhibitor deficiency. Allergy 2011;66:76-84. doi: 10.1111/j.13989995.2010.02456.x
17. Squeglia V, Barbarino A, Bova M, et al. High attack frequency in patients with angioedema due to $\mathrm{C} 1$-inhibitor deficiency is a major determinant in switching to home therapy: a real-life observational study. Orphanet J Rare Dis 2016; 11:133.doi: 10.1186/s13023.016.0518-8.

18. Nordenfelt P, Nilsson M, Björkander J, Mallbris L, Lindfors A, Whalgren CF. Hereditary angioedema in Swedish adults: report from the national cohort. Acta Derm Venerol 2016;96:540-5. doi: 10.2340/00015.555.2274.

19. Gomez-Traseira C, Perez-Fernandez E, Lopez-Serrano MC, et al. Clinical pattern and acute and long-term management of hereditary angioedema due to $\mathrm{C} 1$-esterase inhibitor deficiency. J Investig Allergol Clin Immunol 2015;25:35864.

20. Zanichelli A, Vacchini R, Badini M, Penna V, Cicardi M. Standard care impact on angioedema because of hereditary C1 inhibitor deficiency: a 21-month prospective study in a cohort of 103 patients. Allergy 2011;66:192-6. doi: 10.1111/j.1398-9995.2010.02433.x.

21. Ren HL, Zhang HY. Clinical features of hereditary angioedema: analysis of 133 cases. Zhonghua Yi Xue Za Zhi 2007;87:2772-6.

22. Gelfand JA, Sherins RJ, Alling DW, Frank MM. Treatment of hereditary angioedema with Danazol. Reversal of clinical and biochemical abnormalities. N Engl J Med 1976;295:1444-8. doi: 10.1056/NEJM197.612.232952602.

23. Bork K, Bygum A, Hardt J. Benefits and risks of Danazol in hereditary angioedema: a long term survey of 118 patients. Ann Allergy Asthma Immunol 2008;100:153-61. doi: 10.1016/S1081-1206(10)60424-3.

24. Riedl MA. Critical appraisal of androgen use in hereditary angioedema: a systematic review. Ann Allergy Asthma Immunol 2015;114:281-8. doi: 10.1016/j.anai.2015.01.003.

25. Cicardi M, Suffritti C, Perego F, Caccia S. Novelties in the diagnosis and treatment of angioedema. J Investig Allergol Clin Immunol 2016;26:212-1. doi: 10.18176/jiaci.0087

26. FarkasH,VeszeliN, CsukaD, etal. Managementofpregnancies in a hereditary angioedema patients after treatment with attenuated androgens since childhood. J Obstet Gynaecol 2015;35:89-90. doi: 10.3109/01443.615.2014.925860.

27. Zuraw BL, Busse PJ, White M, et al. Nanofiltered C1 inhibitor concentrate for treatment of hereditary angioedema. N Engl J Med 2010;363:513-22. doi: 10.1056/NEJMoa0805538.

28. Craig T, Shapiro R, Vegh A, et al. Efficacy and safety of an intravenous C1-inhibitor concentrate for long-term prophylaxis in hereditary angioedema. Allergy Rhinol (Providence). 2017:1:8:13-19. doi: 10.2500/ar.2017.8.0192

29. Ucar R, Arslan S, Baran M, Caliskaner AZ. Difficulties encountered in the emergency department by patients with hereditary angioedema experiencing acute attacks. Allergy Asthma Proc 2016;37:72-5. doi: 10.2500/aap.2016.37.3905.

30. Kesim B, Uyguner ZO, Gelincik A, et al. The Turkish hereditary angioedema pilot study (TURHAPS): the first Turkish series of hereditary angioedema. Int Arch Allergy Immunol 2011;156:443-50. doi:10.1159/000323915.

31. Zanichelli A, MagerlM, Longhurst H, Fabien V, Maurer M. Hereditary angioedema with $\mathrm{C} 1$ inhibitor deficiency: 
delay indiagnosis in Europe. Allergy Asthma Clin Immunol 2013;9:29. doi: 10.1186/1710-1492-9-29.

32. Frank MM, Gelfand JA, Atkinson JP. Herediatry angioedema: the clinical syndrome and its management. Ann Intern Med 1976;84:580-93.

33. Agostoni A, Aygören-Pürsün E, Binkley KE, et al. Hereditary and acquired angioedema: problems and progress: proceedings of the third $\mathrm{Cl}$ esterase inhibitör deficiency workshop and beyond. J Allergy Clin Immunol 2004;114(3 Suppl):S51-131.

34. Agostoni A. Cicardi M. Hereditary and acquired C1-inhibitor deficiency: biological and clinical characteristics in 235 patients. Medicine (Baltimore) 1992;71:206-15.

35. Bork K, Meng G, Staubach P, Hardt J. Hereditary angioedema: new findings concerning symptoms, affected organs, and course. Am J Med 2006;119:267-74. 